\title{
SERIAL STUDIES OF SYNOVIAL FLUID IN EVALUATING INTRA-ARTICULAR AGENTS
}

\author{
BY \\ FRANK K. AUSTEN AND EVAN CALKINS \\ From the Department of Medicine, Harvard Medical School, \\ and the Medical Services of the Massachusetts General Hospital
}

(RECEIVED FOR PUBLICATION APRIL 13, 1955)

This is publication No. 184 of the Robert W. Lovett Memorial for the Study of Crippling Diseases, Harvard Medical School, Boston.

One of the most difficult problems in the study of rheumatic diseases is the evaluation of an antiinflammatory response. That this is true in intraarticular as well as systemic therapy is illustrated by the divergence of results reported in the literature. For example, Cohen and others (1954) concluded, by purely clinical evaluation in a large number of patients, that cortisone acetate was equally as effective as hydrocortisone acetate, while studies based on more objective criteria by Duff and others (1951), Hollander and others (1951), Stevenson and others (1952), Ziff and others (1952), and Kersley and Desmarais (1952) clearly demonstrated its relative ineffectiveness.

The present study poses two questions:

(1) What are the changes in the synovial fluid examined by the usual techniques after the intraarticular administration of an agent of known effectiveness-hydrocortisone acetate?

(2) Will serial analyses of synovial fluid permit evaluation in a limited number of patients of an agent of unknown effectiveness-hydrocortisone?

The latter preparation differs from hydrocortisone acetate in its increased solubility in synovial fluid (Macek and others, 1952), and is, therefore, of considerable theoretical interest.

\section{Method}

108 knee-joint aspirations were performed on ten patients with active rheumatoid arthritis with effusions of the knee, bilateral in two. The patients ranged from 29 to 69 years of age and the duration of disease from 2 months to 36 years. The patients were fasting at the time of each procedure. The puncture site was infiltrated with 1 per cent. procaine. After one or two control aspirations, $1 \mathrm{ml}$. of a steroid suspension $(50 \mathrm{mg} . / \mathrm{ml}$.) was administered intra-articularly to each patient. Serial aspirations, removing all available fluid, were then performed on approximately the second, fourth, and sixth day, and later, if necessary, until the characteristics of the fluid had returned to their original pattern. The patients were then given the next test substance and the response was followed in a similar manner. Nine of the patients received hydrocortisone acetate $(50 \mathrm{mg} . / \mathrm{ml}$.), ten hydrocortisone $(50 \mathrm{mg} . / \mathrm{ml}$.), three a placebo containing $50 \mathrm{mg}$. cholesterol, and three a saline placebo. The suspending media in each instance was identical and consisted of physiological salt solution containing $4 \mathrm{mg}$. Polysorbate 80 , and $5 \mathrm{mg}$. $/ \mathrm{ml}$. carboxymethylcellulose, preserved with 0.9 per cent. benzyl alcohol. The order of administration of the drugs was varied from patient to patient, and in a number of instances the same preparation was administered successively to the same patient. Because it was soon observed that the synovial fluid alterations were of much longer duration after the instillation of hydrocortisone acetate this steroid was usually the last to be evaluated.

Each synovial fluid sample was analysed by the techniques customarily used in this clinic (Ropes and Bauer, 1953). These included:

Volume of fluid available by aspiration;

White blood cell count with saline diluent;

Differential cell count;

Nature of mucin precipitate obtained in 1 percent. acetic acid (Ropes and Bauer, 1953);

Viscosity determined by Hess viscosimeter;

Blood and synovial fluid sugar by "macro" method (Folin and Wu, 1920; Folin, 1929).

Not all determinations were performed on each aspirate because occasionally the volume of fluid obtained was inadequate.

\section{Results}

A comparison of the effect of hydrocortisone and hydrocortisone acetate injected intra-articularly is summarized in the Table (overleaf).

The extent of symptomatic relief was based on the patient's own evaluation of the agents. Care was taken not to inform the patients whether a given aspiration was merely for study or whether a steroid or placebo was being administered. The greater incidence and degree of symptomatic relief following hydrocortisone acetate is noteworthy.

Serial aspiration without instillation of an agent or with injection of a saline placebo demonstrated that, within 2 days of a given aspiration, the volume 
TABLE

COMPARISON OF THE EFFECTS OF HYDROCORTISONE AND HYDROCORTISONE ACETATE INJECTED INTRA-ARTICULARLY

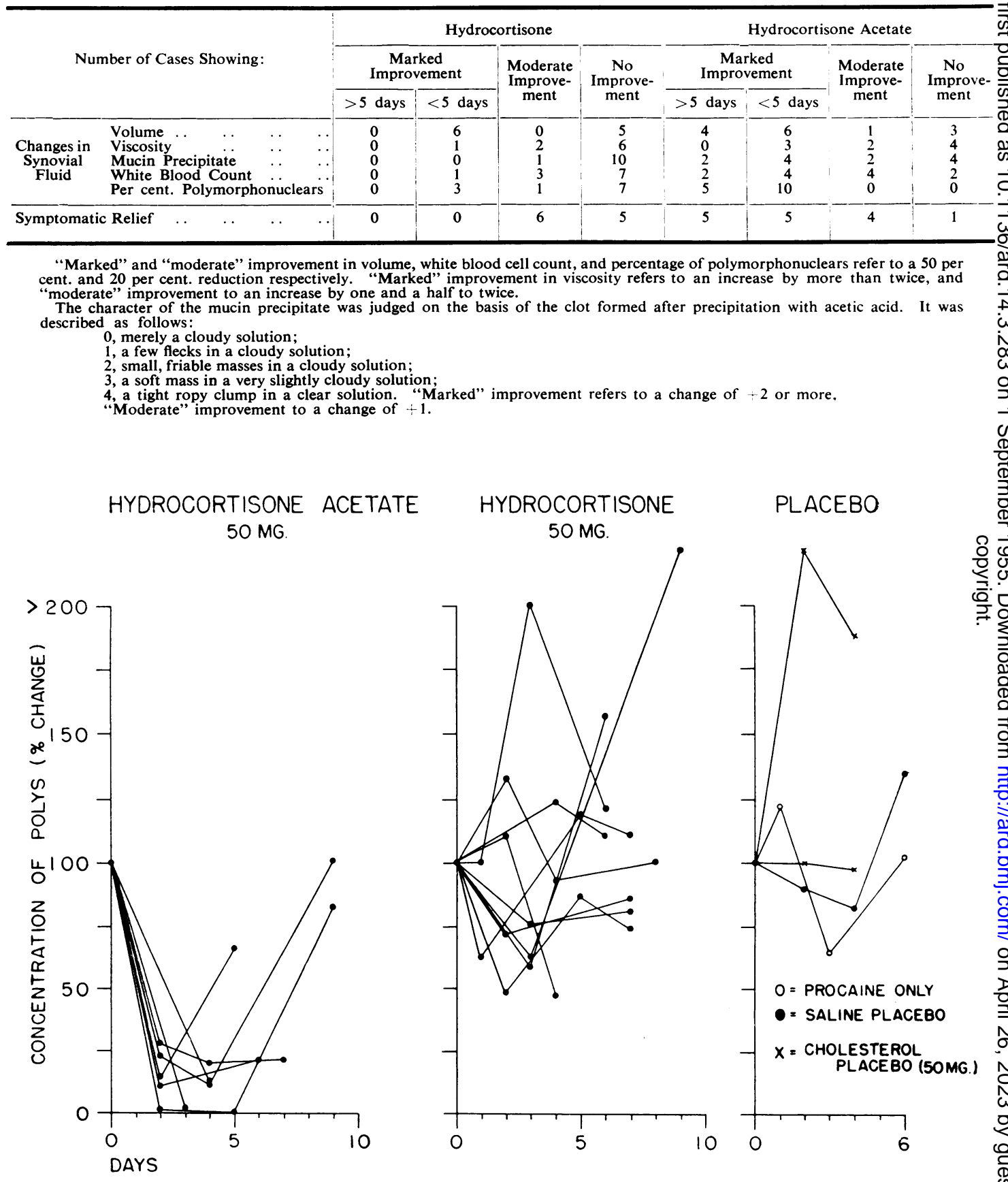

Fig. 1.-Changes in concentration of polymorphonuclear cells occurring after intra-articular instillation of identical doses of hydrocortisone, $\stackrel{\mathscr{C}}{+}$ hydrocortisone acetate, and the indicated placebos. The results designated procaine represent a series of diagnostic taps using procaine anaesthesia in the routine fashion. 
and characteristics of the fluid were approximately as before. After the administration of both steroid preparations there was a significant decrease in the rate of re-accumulation of fluid. Nevertheless, the duration of effect was clearly greater after the hydrocortisone acetate. Similarly, there was a somewhat higher incidence and magnitude of improvement in both the viscosity and the character of the mucin after the hydrocortisone acetate.

The effect of these agents on the white blood cell count and percentage of polymorphonuclear cells is depicted in Figs 1 and 2. The response to hydrocortisone and the placebo varied widely, but after the hydrocortisone acetate there was a consistent fall in the white blood cell count and especially in the percentage of polymorphonuclear cells. The difference in the response to the two agents is particularly evident in Fig. 1, which records the changes in the absolute polymorphonuclear cell concentration. In contrast with the hydrocortisone and the placebo, the hydrocortisone acetate in every instance produced an unequivocal reduction.

Fig. 3 (overleaf) reveals that, after administration of hydrocortisone acetate, the difference between blood sugar and synovial fluid sugar diminished, whereas after hydrocortisone this difference was usually augmented. This fact, together with the occasional rise in absolute polymorphonuclear concentration, suggests that an irritative response to hydrocortisone can sometimes occur.

The saline placebo was used in three instances without demonstrable subjective or objective change.
HYDROCORTISONE ACETATE $50 \mathrm{MG}$.
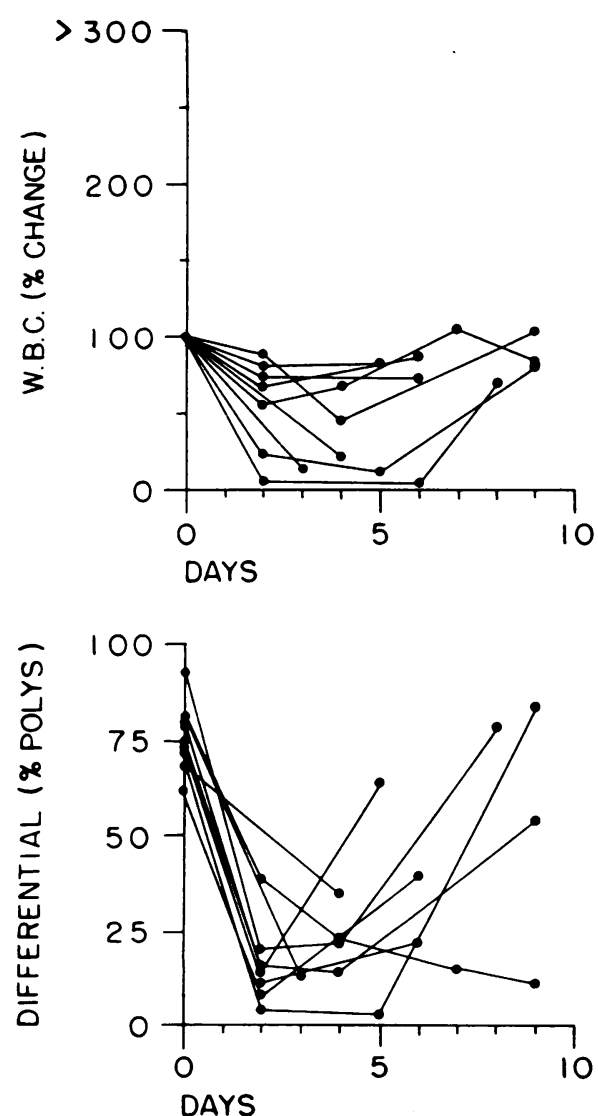

HYDROCORTISONE $50 \mathrm{MG}$.
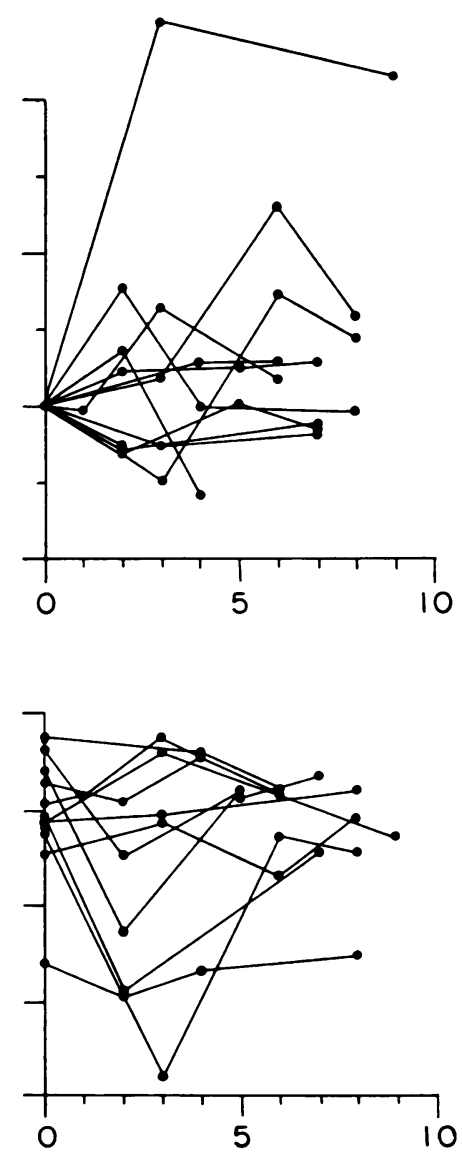

Fig. 2.-Changes in white blood cell count and percentage of polymorphonuclear cells occurring after intra-articular administration of identical doses of hydrocortisone and hydrocortisone acetate $(50 \mathrm{mg}$.). In each series of observations the initial leucocyte count is arbitrarily set at 100 per cent. and subsequent values are related to this initial count. 
In two instances the cholesterol placebo produced no adverse response, symptomatic or by analysis of the fluid; in one case its instillation was followed by a striking symptomatic exacerbation, a marked rise in the white blood cell count and percentage of polymorphonuclear cells, and a deterioration of the mucin precipitate. Subsequent instillations of the saline placebo and hydrocortisone were not accompanied by a similar exacerbation.

In the four instances in which eosinophil counts were performed after treatment with $50 \mathrm{mg}$. hydrocortisone, a fall greater than 50 per cent. occurred either 4 or $8 \mathrm{hrs}$ later. In the two instances in which hydrocortisone acetate was injected the fall was no more than with routine aspiration (15 per cent.).

\section{Discussion}

Significant changes toward normal in the synovial fluid appeared more consistently and were of greater magnitude and duration after the injection of hydrocortisone acetate than after hydrocortisone. These results are at variance with the conclusions of Hollander and others (1951), who reported on the basis of clinical evaluation that the two preparations were equally effective.

The patient's subjective evaluation of each agent correlated rather well with the fall in synovial fluad polymorphonuclear concentration and the slow rat of re-accumulation of synovial fluid. That some patients reported symptomatic relief without ev? dence of associated objective changes probably resulted from the attention associated with aspirz tion and from lessening of the intra-articular pressure. It is of interest that, in many instances the patient's estimation of clinical improvement clearly outlasted demonstrable objective changes. $\overline{2}$

Serial synovial fluid analyses after the injectio of the steroids demonstrated considerable variationp in degree and duration of effect with the same ageris in different patients, and illustrated that any cons:bination of changes may occur. An improvemerit in the character of the mucin was usually associated

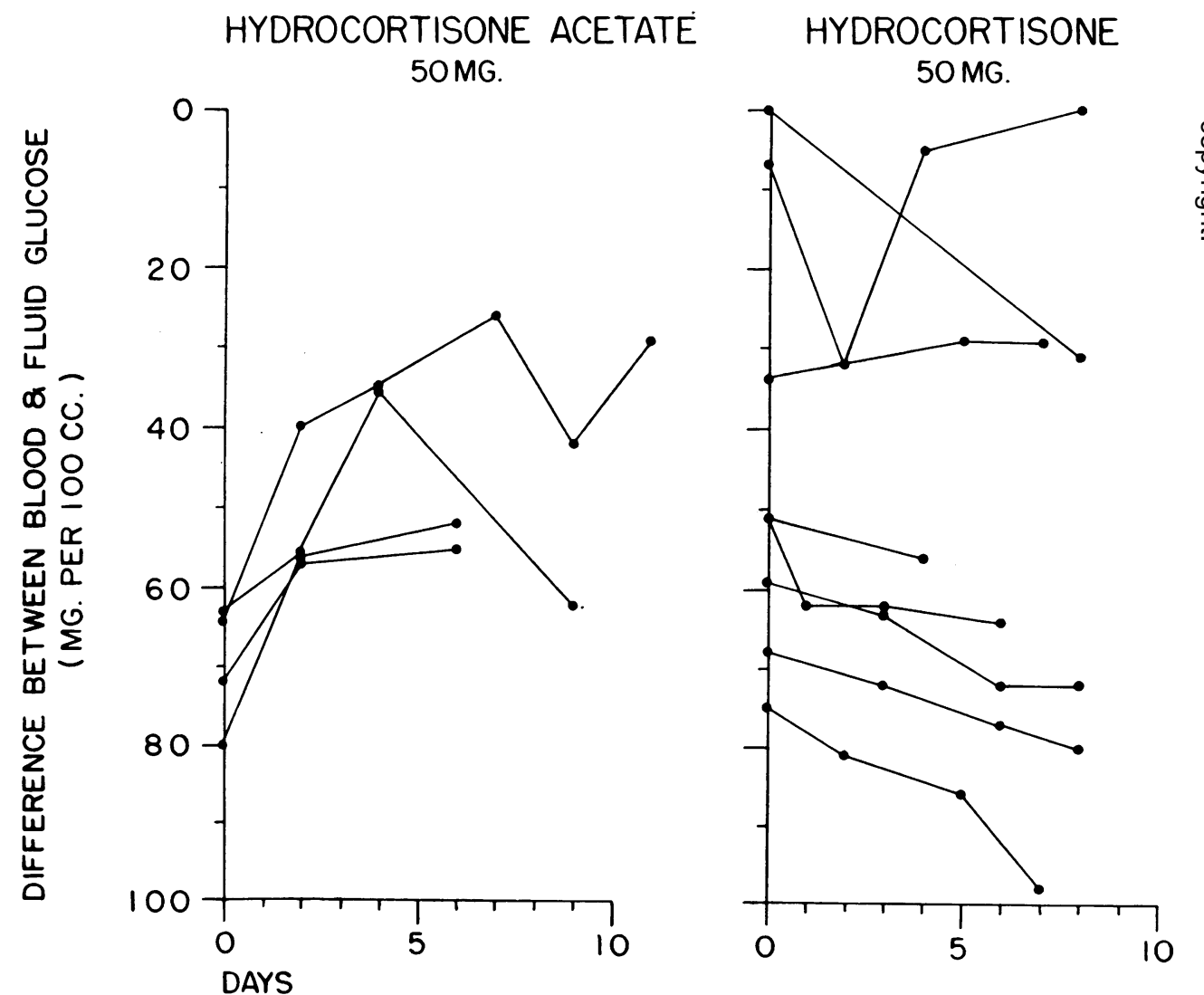

Fig. 3.-Difference between simultaneously determined glucose concentrations in serum and synovial fluid (plotted inversely on ordinate) an change with time. Upward slope indicates improvement. 
with a rise in viscosity. These changes, which may mean repolymerization of the hyaluronic acid (Duff and others, 1951), appeared in a few instances after the administration of hydrocortisone, even without an associated anti-inflammatory effect, as measured by a fall in the leucocyte count or in the percentage of polymorphonuclear cells. Ropes (1955) has found that with cortisone acetate there may also occur rises in viscosity without an associated anti-inflammatory effect.

Demonstration of the greater effectiveness of hydrocortisone acetate compared to hydrocortisone may have theoretical connotations. Wilson and others (1953) found that hydrocortisone, cortisone, and their acetates disappeared with equal rapidity from cell-free synovial fluid, despite the fact that hydrocortisone is seven times more soluble in synovial fluid than hydrocortisone acetate (Macek and others, 1952). Zacco and others (1954), while confirming this work, demonstrated that hydrocortisone acetate led to a greater concentration of 17-hydroxycorticoids in the cellular fraction of synovial fluid than did hydrocortisone. However, because they did not find any difference in the clinical effectiveness of these two preparations, they did not attempt to correlate relative insolubility, cellular concentration, and clinical efficacy. The belief that relative insolubility is, at least, an important factor in the effectiveness of steroids placed intra-articularly is supported by our series, in which hydrocortisone was demonstrably less effective than hydrocortisone acetate. The fall in eosinophils which occurred after hydrocortisone, but not after hydrocortisone acetate suggests that the more soluble hydrocortisone entered the systemic circulation.

\section{Summary}

(1) The synovial fluid changes after intraarticular injection of an effective steroid preparation are demonstrated by serial analyses, and the variation in duration and pattern of response is illustrated.

(2) Evidence is presented that significant changes in synovial fluid appeared more consistently and were of greater magnitude and duration after injection of hydrocortisone acetate than after injection of hydrocortisone.

(3) It is suggested that the esterified form of the steroid molecule is more effective because it is less soluble.

(4) The usefulness of objective criteria in evaluating an anti-inflammatory response is illustrated.

Grants in support of these investigations have been received from the Commonwealth Fund, New York City, and from the United States Public Health Service.

The authors wish to express their appreciation to Miss Phoebe Krey for her assistance in performing many of the technical procedures.

All materials for intra-articular injection used in this study were prepared for us by the Upjohn Company, Kalamazoo, Michigan, through the courtesy of Dr. H. F. Heilman.

\section{REFERENCES}

Cohen, A., Rose, I., and Seven, M. J. (1954). New Engl. J. Med., 250, 507.

Duff, L. F., Robinson, W. D., and Smith, E. (1951). J. Lab. clin. Med., 38, 805.

Folin, O. (1929). J. biol. Chem., 82, 83.

- , and Wu, H. (1920). Ibid., 41, 367.

Hollander, J. L., Brown, E. M., Jessar, R. A., and Brown, C. Y. (1951). J. Amer. med. Ass., 147, 1629.

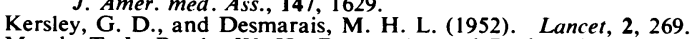

Macek, T. J., Baade, W. H., Bornn, A., and Bacher, F. A. (1952). Science. 116, 399.

Ropes, M. W. (1955). Personal communication.

- , and Bauer, W. (1953). "Synovial Fluid Changes in Joint Disease." Commonwealth Fund Book, Harvard University Press, Cambridge, Mass.

Press, Cambridge, Mass.
Stevenson, C. R., Zuckner, J., and Freyberg, R. H. (1952). Annals of the Rheumatic Diseases, 11, 112.

Wilson, H., Glyn, J., Scull, E., McEwen, E., and Ziff, M. (1953). Proc. Soc. exp. Biol.' (N. Y. ), 83, 648 .

Zacco, M., Richardson, E. M., Crittenden, J. O., Hollander, J. L., and Dohan, F. C. (1954). J. clin. Endocr., 14, 711.

Ziff, M., Scull, E., Ford, D., McEwen, C., and Bunim, J. J. (1952). Arch. intern. Med., 90, 774.

\section{Etude en série du liquide synovial dans l'évaluation des agents intra-articulaires}

\section{RÉSUMÉ}

(1) Par des analyses en série on met en évidence les altérations du liquide synovial après des injections d'une préparation stéroïde active et on décrit les variations de la durée et du type de la réaction.

(2) On présente des données montrant que les altérations significatives du liquide synovial sont plus constantes, plus grandes et plus durables après l'injection d'acétate d'hydrocortisone qu'après l'injection d'hydrocortisone.

(3) On suggère que la molécule stéroïde estérifiée est plus efficace parce qu'elle est moins soluble.

(4) On montre la valeur des critères objectifs dans. l'évaluation de la réaction anti-inflammatoire.

\section{Estudio en serie del líquido sinovial en la avaluación de los agentes intra-articulares}

\section{Sumario}

(1) Por medio de análisis seriados se demuestran las alteraciones del líquido sinovial después de inyecciones de una preparación esteroide activa y se describen las variaciones de la duración y del tipo de la respuesta.

(2) Se presentan datos mostrando que las alteraciones significativas del líquido sinovial son mayores, más constantes y duraderas con inyecciones de acetato de hidrocortisona que con las de hidrocortisona.

(3) Se sugiere que la molécula esteroide esterificada es más eficaz por ser menos soluble.

(4) Se demuestran las ventajas de los criterios objetivos en la avaluación de la reacción ani-inflamatoria. 